\title{
Community-Based Water Governance under Integrated Water Resources Management Reform in Contemporary Rural China
}

\author{
Haiyan Helen Yu (Corresponding author) \\ School of Geography and the Environment, University of Oxford \\ South Parks Road, Oxford, OX13QY, UK \\ Tel: 44-078-3185-6488Ｅ-mail: haiyan.yu@ ouce.ox.ac.uk
}

Received: May 21, 2014 Accepted: June 10, 2014

doi:10.5296/emsd.v3i2.5656 URL: http://dx.doi.org/10.5296/emsd.v3i2.5656

\begin{abstract}
Studying water governance at multiple levels can link national or regional objectives with local development priorities. Improving water governance requires rethinking water issues through multiple perspectives, and strategic uses of cooperative partnerships and deliberative processes. Understanding community-based water governance (CBWG) has a critical role to play in constructing a broad pluralistic approach to successful water governance, which starts from the lowest level of local water users' groups; and involves networks and linkages across different levels. This paper takes an empirical focus on CBWG processes and outcomes under China's powerful enforcement of integrated water resources management (IWRM). It shows that CBWG combined with poorly developed policies and lack of multi-level cooperation can reinforce destructive practices in collective forms which are more dangerous, costly and difficult to detect. It concludes that communities have an important role to play in global water governance especially in constructing localized and polycentric frameworks for successful water governance, however community-based water governance per se like market-based or centralized governance as a panacea is insufficient. Approaches are needed that enable in-depth understanding of multi-level institutions in polycentric policy development and implementation, whilst incorporating flexibility to account for physical, socio-economic and political specificities.
\end{abstract}

Keywords: Irrigation commons, complexity, community-based water governance (CBWG), collective action, social capital, IWRM, China 


\section{Introduction}

The pressing global water crisis is a crisis of governance rather than a crisis of physical scarcity (Rogers \& Hall, 2003). Traditional solutions which largely relied on technocratic solutions, market-based approach such as privatisation (Huang, Wang, Easter, \& Rozelle, 2010) and government control (J. Nickum, 2010; Sadiddin, 2013), have been widely adopted by much of the world as the main if not the only way to achieve sustainable water governance. However some of the water problems seem to persist if not getting worse (Huang et al., 2010).

Water governance refers to the political, social, economic and administrative systems that develop, manage and distribute water resources (Roger 2003). It involves both formal institutions such as government agencies, laws and policies; and informal institutions such as shared rules, customs and norms that impact water management (E. Ostrom, 1990). Both are relevant to water governance activities and interact with each other horizontally and vertically in determining how people perceive water resources, make water decisions, carry out responsibilities, ensure accountabilities and articulate their interests. Water governance is a complex social-ecological process that needs to be addressed not only through managing water resources but also through better understanding of the people targeting them and the relationship intertwined throughout the management processes (Mollinga, S, \& Wester, 2008; Pahl-Wostl, 2002).

Irrigation water governance has been treated as a CPRs (Common Pool Resources) problem (Mosse, 2006; Olson, 1965; Tang, 1992), specifically a multi-level CPRs problem (E. Ostrom, 1990). Moreover natural environment itself is a complex system as well with issues of scale, uncertainty and dynamics. In addition, the social systems within which water governance are embedded, are also complex and multi-level (Mehta, 2003) with institutions and organizations from local, regional, national to international levels (Berkes, 2002). Since each level or a scale is different, the perspectives from each level also largely differ. For instance the perspectives on water governance at regional or national levels may be different from the local lenses which favour short-term economic benefits rather than long-term sustainability. Recognizing this complexity, state control or the market alone would be an insufficient solution to sustainable governance of the irrigation commons especially in a hierarchical environment with each level being nested in and linked to a larger subsystem.

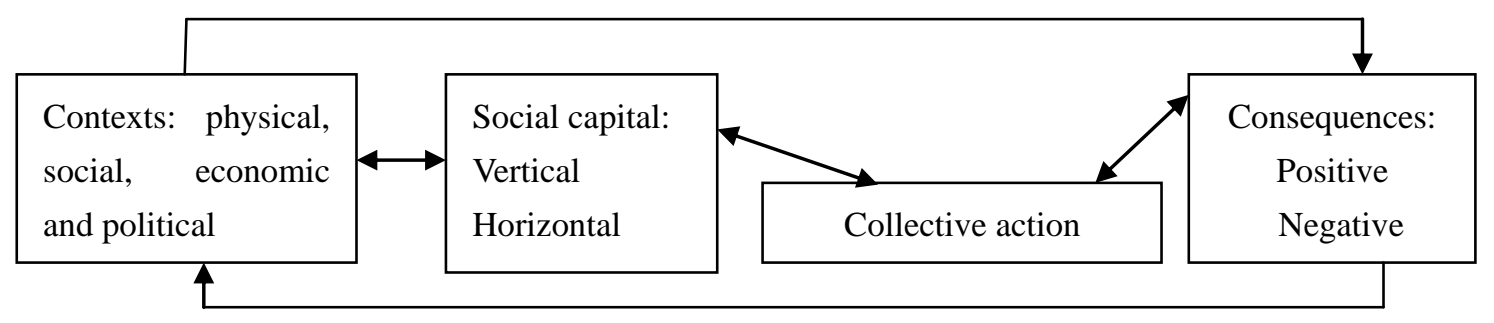

Figure 1. The CPRs governance model. Source: author.

Issues over whether community-based governance can lead to conservation and sustainable water governance has been hotly debated (Agrawal, 2014; Akono, 2013; Brandt \& Svendsen, 2013; Olson, 1965; E. Ostrom, 1990; Elinor Ostrom, 2010; Wade, 1987). Scholars have emphasized the significance of CBWG (community-based water governance) at local levels 
(Agrawal, 2014; Baland \& Platteau, 2007; Lejano \& Fernandez de Castro, 2014; Narayan, 1995; Olson, 1965; E. Ostrom, 1990; Tang, 1992; Wade, 1987). There are various names of CBWG, including participatory water governance, participatory irrigation management, irrigation management transfer and water decentralization (Johnson III, 1997; Nian, 2001; Solanes, 1995; Wang, Huang, Zhang, Huang, \& Rozelle, 2010). In contrast with state and market based approaches, CBWG is more inclusive, sensitive and responsive to local needs and contexts (Nian, 2001; E. Ostrom, 1990; Pahl-Wostl, 2002; Pretty, 2003), since communities can more effectively garner and disperse localized information (Berkes, 2009) at lower cost (Lam et al., 2005). The concept of CBWG or participatory water governance is also one of the key principles of (Integrated Water Resource Management) IWRM, a prevailing water paradigm (GWP, 2000; Jonch-Clausen, 2004; Jordi, 2013; Savenije \& Vanderzaag, 2008).

However water governance mechanism developed from one case at a certain time is not readily transferable to another or even to itself at a different time (Tortajada, 2010). For example, community-based organizations such as WUAs, developed in one area and replicated globally with little attention to the contexts, have largely been unsuccessful (Agarwal, 2001; Gastineau, 2006; Sonal, 2013). Therefore the key question in this paper is: despite all these differences, can communities self-govern resources efficiently and sustainably; or as many of its predecessors, has it become just another blueprint panacea that every project and donor pursues?

Investigation of multiple perspectives from a variety of stakeholders at local level is a very good starting point. However, despite the popularity and high stakes of these factors, there has been little empirical study related to stakeholders' water perceptions in China. This paper stresses that all related perspectives, either scientific evidence or indigenous knowledge, either from local or central levels should be well understood and taken into account in water planning and governance (Kamoto, Clarkson, Dorward, \& Shepherd, 2013; Lee \& Zhang, 2004), a point often missed in extant approaches.

In this paper, the author used analysis of empirical studies from arid and semi-arid regions of a typical inland river basin, the Shiyang River Basin (SRB) in Northwest China, to explore CBWG activities under the government scheme of IWRM. It argues that implementing governance mechanisms to deal with the complexity of water governance requires multiple perspectives and deliberative polycentric processes to provide appropriate incentives, cooperative partnerships and a learning by doing process among different stakeholders rather than nominal implementation of reforms and policies such as IWRM in studied area. CBWG is part of the mechanisms to address governance problems of CPRs that cannot be handled by individuals, state control or the market alone; however community governance itself is insufficient for sustainable water governance.

\section{Importance of Networks and Deliberative and Localized Processes}

A key characteristic of governance of CPRs is the presence of multiple stakeholders, embedded networks and social capital (Giest \& Howlett, 2014; Lam et al., 2005; Lejano \& Fernandez de Castro, 2014; Narayan, 1995; E. Ostrom, 1990; Tang, 1992). Trust, reciprocity and fact-to-face 
communication are three key predictors for successful collective actions (E. Ostrom, 1990; Pretty, 2003). There are key alliances within the collective processes through which different parties bring their knowledge and strength and contribute in governing the water commons. Despite the diverse physical, socio-economic, political and cultural backgrounds, these stakeholders interact with each other on regular basis to provide a range of services and capital that successful governance process apparently requires, including raising funds, institution building, networking, knowledge transfer and decision making in dynamic manner (Yu et al 2014).

Cooperative partnership from both within communities (horizontal relations) and outside (vertical relations) that takes local needs and incentive as well as external ones into account requires easily accessible information exchange and effective interaction among different parties. These interactions are referred to as localized and deliberative processes for communication and collectively raising issues in which different parties exchange observations, reflect on information, assess outcomes and engage in related discussions and decision making (Yu, Lora-Wainwright, Edmunds, \& Thomas, 2013). These processes enable diverse input of knowledge of stakeholders at different levels and complement solutions that are merely based on scientific knowledge (Pahl-Wostl, 2002). The localized negotiation and bargaining processes enable reconciliation of these differences in a cost-effective and efficient manner (Lejano \& Fernandez de Castro, 2014).

\section{The Chinese Context}

Water crisis has been identified as one of the key problems threatening China's ambitious economic development plans and the Communist party's need to maintain its continuous governing legitimacy. Over the years, rapid socio-economic growth, an increasing demand for limited and unevenly distributed water resources (temporally and spatially); a large and growing population and changing to more water-intensive lifestyles, have added to China's water pressure (Jiang, 2009; MWR, 2007). Agriculture sector remains one of the largest water consumers in China (Yu, Edmunds, Lora-Wainwright, \& Thomas, 2014), even though it is no longer given any priority in water allocation (Huang et al., 2010). This has exacerbated local agriculture production, food security and people's livelihoods (Ma, Wang, \& Edmunds, 2005; Yu et al., 2013), especially for the poorer farmers and disadvantaged groups who are most resource-dependent (Yu et al., 2014).

The study was carried out in communities in the arid and semi-arid regions of the Shiyang River Basin (SRB). It lies in the Gansu Province, Northwest China and is surrounded by the Bardan Jaran and Tenggli Deserts (Figure. 2). The majority of the water feeding the SRB is from glacier and snow-melt in the upper stream mountainous area. Flowing down the basin, the river provides freshwater for irrigation to local villagers and disappears in the downstream desert area. With an arid continental climate, the average annual rainfall is $222 \mathrm{~mm}$ and evaportranspiration is around $2000 \mathrm{~mm}$ to $3000 \mathrm{~mm}$ (Ma et al., 2005). For over 8 months each year, there is no precipitation. In other words no irrigation in this area means no agriculture and no income for the majority of local population. Irrigation plays a central role in the socio-economic development and stability. The area is one of the poorest districts in China. 


\section{Macrothink}

Actually poor is rather generic when $77 \%$ of a population of 2.5 million largely depends on small-scale irrigated agriculture (per capita land holding is $0.16 \mathrm{ha}$ ) for their livelihoods.

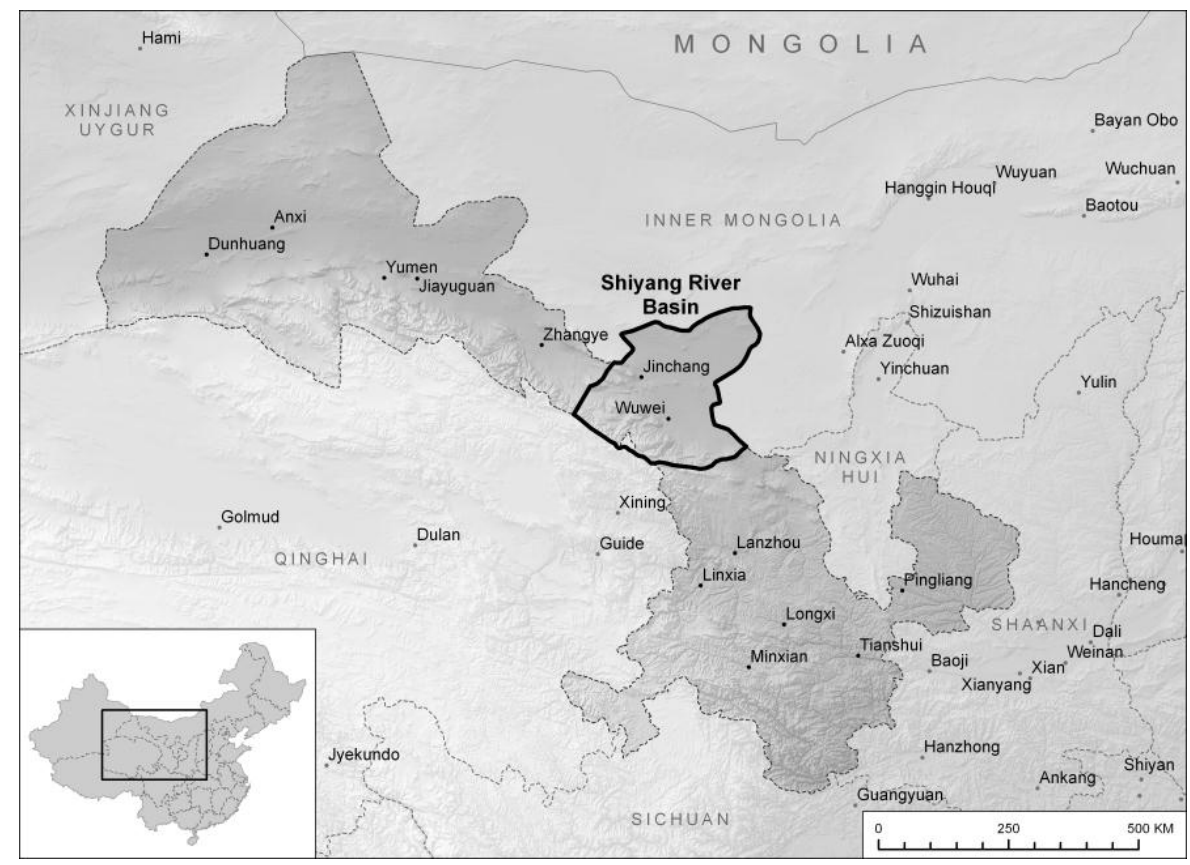

Figure 2. Location of the Research Area

The ownership of water resources in China belongs to the state (Liu \& Speed, 2009). Water is governed through a highly centralized hierarchy and a planned water use system (Shen, 2012) including a water allocation and regulation subsystem; a water abstraction permit subsystem; and a water fee collection system. The actual management of irrigation systems was locally led by village and county level authorities (Xie, 2007). Although the term CBWG or participatory irrigation management was not generally used in China until the 1990s, the practice of community management of irrigation systems, including construction and rehabilitation of infrastructures at tertiary level and below, operation and maintenance of irrigation systems, has a long history (J. E. Nickum, 1974). However, as most other countries, implementation issues regarding participatory and sustainable water governance has always been and continues to be a challenge (Agrawal, 2014; Lam et al., 2005; Wang et al., 2010).

\section{Lessons from the Chinese Case Study}

In terms of outcomes of IWRM reforms, China has provided a mixed picture: with some evidence showing that significant improvements have been achieved in China's water management, others question the applicability of IWRM in China. For example, Biswas (2008) argues that western-based concepts such as IWRM is not possible for large or medium-sized countries such as China. Similarly, Mollinga (2010) and Nickum (2010) suggest that the concept of IWRM may be too embedded in the Western democracy to be useful to Chinese policymakers and those who seek to understand their behaviour. Surprisingly there is very little or no empirical-based literature available to understand detailed IWRM processes in China, which makes it more difficult to assess the reforms systematically (Hussain, 2005). 


\section{Macrothink}

As Agrawal (2014) notes, scholars of the CPRs have for too long neglected the clear differences between different measures and dimensions of governance outcomes of CPRs, using vague terms such as sustainability, success, long-term enduring CPRs institutions interchangeably. Actually successful institutions cannot be perceived the same as sustainable water governance (Yu et al., 2014). They can mean different things to different people, for instance government officials, water authorities, private sectors and local communities. It is crucial to analyze success and failures in a multi-level basis considering the entrenched contexts and extend the analysis to other factors in order to explain the differences in both irrigation institutions and their performances. Results show that despite some success in certain communities, much of the so-called IWRM reforms in the area studied has largely been half-hearted, misdirected and theory ignorant, failed to bring expected and theoretically predicted outcomes.

\subsection{Community Success}

Empirical data is drawn from surveying a large set of 225 interviewees from 91 communities in 11 villages (for details see Figure 3 and Yu et al 2013 and 2014) throughout the SRB. It has shown similar findings that CBWG tend to involve networks and partnerships of various kinds for a variety of purposes. On one hand, the study confirms that despite the specificities in each community, studied cases have managed to identify and satisfy different needs with a cooperative partnership and networks. For example, successful cases of community-based governance are the ones that had networks involving water users, poor or rich, small or large land-holders, while networks and partnership were weak or non-existent, the irrigation governance was more costly and less efficient (Pretty, 2003; Yu et al., 2014).

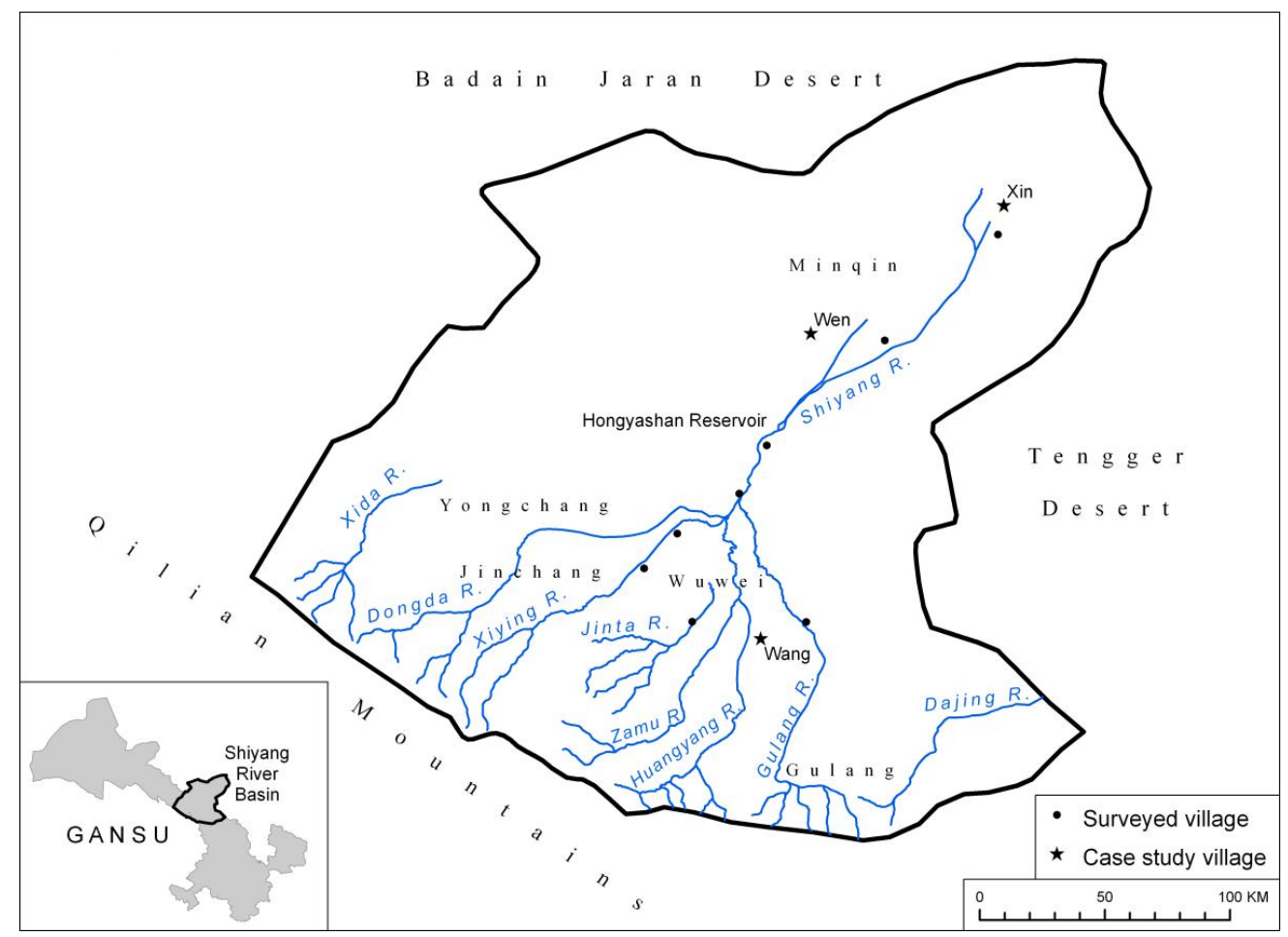

Figure 3. Studied village sites in the Shiyang River Basin 
According to empirical results from this study, all of Ostrom's (1993) design principles for successful, long-enduring CPRs institutions are indentified in studied communities case either in the form of traditional collective management or private contracting system (Yu et al., 2014). With clear boundaries for water resources and related services villagers devised rules matching rules to local conditions and used participatory modification, monitoring, graduated sanction and conflict resolution mechanisms which are a mixture of formal and informal institutions in different settings. The working rules have been locally devised and constantly modified over time through communal discussions and agreements. Irrigation related activities were largely dependent on irrigators' contribution of labour, information and investments among others. Besides, these institutions have also shown the features of successful institutions suggested by others such as Crase and Gandhi (2009), including clear objectives, connectedness, adaptability, appropriate of scale and compliance. Users are long-term residents who are familiar with local environment. The resources lie close to users. Irrigation is a repetitive activity that happens several times in a growing season. All these make rule infringements within communities very rare. In all, villagers have been clearly capable of organizing themselves in different forms to manage water resources within their communities in a locally efficient, cost effective, transparent and equitable manner with no presence of external authority. Thus, to a certain degree one should not hesitate to call these studied irrigation institutions effective and successful (E. Ostrom, 1990). However, is meeting these principles enough in ensuring sustainable governance and uses of the irrigation commons at community scale?

\subsection{Community Failures}

Previous studies have shown that community-based management process can be complex and elusive (Lejano \& Fernandez de Castro, 2014; Olson, 1965; E. Ostrom, 1990; Wade, 1987). Like market- and state-based approaches, communities also fail (Lane \& McDonald, 2005; E. Ostrom, 1990). Kellert et al (2000) for example through examining implementation outcomes of community-based resource governance in Nepal, Kenya and US, shows serious deficiencies of community-based governance. More recently Kamoto et al (2013) have found that poorly developed and implemented community-based natural resource management policies can actually do more harm than good in natural resources management. Blaikie (2006) also suggest that evaluation of community based resource management has been evidently absent and largely disappointing. In the studied area or in China generally monitoring and evaluations of CBWG programs have been largely nonexistent so that voices of communities themselves have not been articulated or appropriately heard.

Outcomes of community-based irrigation governance in SRB were examined in three main aspects from communities' experiences and perspectives: (1) irrigation efficiency; (2) equity and empowerment; (3) sustainability. First of all, examined case studies of community-based resource management show that irrigation efficiency has not been improved and overexploitation specifically of groundwater resource has been and still is obvious. For example in one case study, most informants $(51.4 \%, \mathrm{~N}=30)$ expressed that irrigation quantity per unit area has not changed and $40.5 \%$ expressed that their water uses have actually increased. Although it was often difficult to determine whether participants' negative responses reflect the actual situation or is just because of the unfavourable reforms, it seemed clear that IWRM 
reforms aimed for a more integrated and participatory water governance did not reduce the frequency or the quantity of irrigation. The situation became more compelling when villagers repeatedly expressed that, they had to irrigate more than what they did before the reform whenever they have irrigation access, considering the increasing uncertainty caused by government water reforms and control.

Community-based IWRM reforms did not have a significant effect on changes in equity or local empowerment either. In other words, the links between community participation and existence of participatory water policies and increased equity are not always straightforward. Other factors such as capable and well connected local leaders particularly at village and community levels will condition how people may react to or benefit from IWRM reforms. In contrast with most extent findings which show the negative impact of community-based governance as elite capture and increase inequity between participants and non-participants, our results show that it is the inequity among different communities and villages that has increased rather than within communities, which appeared to be more dangerous, for example increased rent-seeking, infringement of official regulations and destructive irrigation practices collectively (See Yu et al 2014 for details).

In the cases studied, socio-economic goals such as food and water security and income were still given a much higher priority, at times compromising the objective of sustainable uses. Interviews with local communities revealed most of the attention was focused on community development and livelihoods security, while sustainability goals were still largely underemphasized especially among villagers. Actually, communities tended to overuse water resources for socio-economic benefits under the perception of "develop first, fix the problems later when people are richer and more capable". In other words, in some villages studied local communities often set their irrigation quotas with little or no consideration of whether these levels were sustainable over long term.

\subsection{Impacts of Indigenous Knowledge}

Indigenous knowledge is a body of knowledge that have been developed orally and communicated among its members, and is often adjusted to local contexts and lasts for generations (Mbilinyi, Tumbo, \& Mahoo, 2005). The significant roles of indigenous knowledge and information regarding to local physical situations, users' needs and behaviours in successful governance of the CPRs have been widely acknowledged (Berkes, Colding, \& Folke, 2000; Kearney \& Bradley, 2011; Lynam, de Jong, Sheil, Kusumanto, \& Evans, 2007; Williams, 1998). For example, our study found that indigenous knowledge facilitated community members' agriculture practices and decision making in a locally adjusted and effective manner (Lejano \& Fernandez de Castro, 2014).

On the other hand, it has been found that local communities do not always have the knowledge that their behaviours are detrimental to the resource base or environment (Pretty, 2003). Largely based on long-term agriculture practice and experiences, villagers' knowledge of water, land and environmental system can be inaccurate sometimes. It is uncommon for agriculture communities studied to believe that groundwater resources were actually being depleted, not to mention relating it with their over-exploitative behaviour, even though scientific evidence has 
shown otherwise (Yu et al., 2013). In much of the cases studies, community-based governance depends on this kind of indigenous information does not favour resource conservation or sustainability, and needs to be strengthened through government support or effective interventions from other levels or organizations such as international agencies or NGOs.

CBWG has been promoted as an effective way to connect indigenous information with scientific knowledge (E. Ostrom, 1990). Cases in this paper indicated the implementation of this goal in practice was rare despite prevalent existence of local policies on consulting local participants in water policy planning, making, implementation and evaluation. There were no consistent, systematic and easily accessible efforts attempting to incorporate local knowledge or rendering scientific understandings to local communities. Nor was any noticeable exchange of information between local communities and government officials observed. Information and knowledge continues to be passed in a one-way, top-down manner.

\subsection{The Roles of Incentives}

Incentives can be defined as mechanisms that motivate stakeholders' water behaviours and their cooperation and participation in collective water management (F. Cleaver, 1998). Incentives may occur when resource-dependent people face scarcity and desire to maximize their benefits of resource use (Suich, 2013). They are also connected with transaction costs, opportunity costs and potential benefits perceived by multi-stakeholders (E. Ostrom, 1990).

China's official evaluation system is based on vertical checks on officials through a hierarchical promotion which is strongly based on economic and fiscal performance. Under its new President China has now abandoned the GDP-centred assessments and put more emphasis on public well-being and environmental performance as an improved gauge of official success. Although being a positive step towards a more balanced and sustainable development mode, it is as Nickum (2010) argues, not hard to imagine the implementation problems such as focus on measurable indices and fulfilling official quotas and sticking to "planned water uses" rather than villagers' welfare or long-term sustainability. For instance, instead of paying attention to meaningful empowerment, public participation was measured only in the number of WUAs established and communities included in so-called participatory processes of manipulation, information or consultation at best, which is only at best the lowest level of participation (Arnstein, 1969). Officials under the "personal responsibility system" are personally held responsible for fulfilling officially set targets and have been forced to accept and implement the official orders even when they negatively impact agriculture production, local income and community welfare. Officials thus have to learn to get around and fulfil these targets or at least to make reported results match the targets (O'Brien \& $\mathrm{Li}, 1999)$. In studied area, this is achieved through, but not confined to hiding authentic records from higher level officials, falsifying reports, selective implementation and illegal use of IWRM project funds.

Local water reforms towards IWRM, introduced the idea of a multiple-objectives approach that promotes coordinated development of water, land and related resources in order to maximize the resultant economic and social welfare in an equitable manner without compromising the sustainability of ecosystems (GWP, 2000). However the development of IWRM plans did not hold up to its promised integration which requires involvement of all related stakeholders, 
networks and partnerships at various levels (Savenije \& Vanderzaag, 2008). In studied area, involving communities in irrigation governance is often used as a means of making government water policies and plans less likely to meet local resistance; making use of local labour contribution in operation and maintenance of irrigation systems; and alleviating government financial burdens rather than increase community autonomy or empowerment.

This study shows that actual integration is rather rare or an abject failure since collaborative governance requires power sharing which contradicts China's traditional and entrenched institutional culture (J. Nickum, 2010). As one respondent commented on established WUAs (Water users' associations),

"WUA is basically the village committee with a different name. The village leaders and team leaders, they are WUA, not us (ordinary water users). We will know what they want us to know or what they think we need to know rather than influencing decision making through participation. Actually there is not much to decide anyway. All decisions have been officially made." (Wang villager N44, male, age 39).

If the incentives of water conservation and development can be simultaneously achieved, the interest of both can be met. This unfortunately is not the case most of the time. What is conceived as benefits by some groups may not be the same or even compatible with others. For instance, sustainability and cost-recovery which are considered as two potential benefits were not popular among villagers. Even within communities, different groups seem to value different things. For instance, older population who have a long history of living locally, depend mostly or entirely on resource-dependent livelihoods and do not have huge financial burdens such as education of their children, favour environmental conservation and a sustainable water development, while for younger generations who are suffering from drastic financial pressures, maximizing economic benefits was a priority.

Moreover, having lived through and benefited significantly from agriculture development through agriculture expansion and excessive resources exploitation over the past few decades, it is difficult to force local communities to turn from economic-centred agriculture patterns to water conservative patterns that will inevitably impact their income adversely. This means, government initiatives and preventions are required to obtain congruence among these diversified incentives and interests, for example, through more involvement of external agencies and organizations in constructing negotiation or cooperative links rather than oppositional relations in management process, and through providing financial or other resources as compensations or incentive to water conservation and sustainability. The SRB case provides an example of how driven by different incentives, a confrontational relationship has been engendered between different parties, with external officials and local communities, each trying to manipulate and bargain with others through negotiating water control.

\subsection{Multi-Dimensions of Social Capital and Collective Action}

Social capital and collective action have always been at the centre of community-based governance of CPRs (Adger, 2010; Giest \& Howlett, 2014; Meinzen-Dick \& Knox, 1999; Pretty, 2003). The use of social capital and collective action had never been independent of 
wider socio-political and cultural systems of state or bureaucracy (Mosse, 2006). While most studies claim that social capital is beneficial in a variety of ways to improve governance outcomes, empirical evidence in this study has shown for the first time both positive and negative consequences in using different dimensions of social capital and collective action.

On one hand, within communities, social capital for example in forms of trust, reciprocity, and face-to-face communication have facilitated collective water governance. Participants depend on irrigated agriculture for a majority of their living and this makes effective irrigation a vital part of their everyday life, which motivates self-interested users to collaboratively manage their irrigation commons in locally effective and efficient manner (Frances Cleaver, 2000; Narayan, 1995; Elinor Ostrom, Burger, Field, Norgaard, \& Policansky, 1999; Tang, 1992). In addition, facing with increasing threat from climate change and external bureaucratic water control, it is widely perceived by local people that they can enjoy a higher degree of security if they cooperate and adapt in accordance with each other. Collective practice helps create a more transparent and equitable system through which all can contribute proportionally, for instance with their irrigated land areas or number of landholders per household. Irrigation has been and continues to be a highly communal and visible activity, thus theft and free-riding within communities were extremely rare. For example, one village responded, "Everybody knows everybody else in here, where their lands are, what they grow, when they irrigate and for how long, all is public knowledge" (Wen villager N31, male, age 59).

On the other hand, this study shows some new evidence that social capital at community level and beyond can be put to genuinely destructive ends and induce negative consequences. For example, when multi-level relations (for example between communities and village leaders or between villagers and external authorities) were deemed as exploitative and corrupt, communities strategically constructed and used horizontal dimensions of social capital, for example in the forms of alliance, collusion or mutual coercion for collective benefits. Such relations were built into community-based water governance processes. The direct outcomes were destructive irrigation practices, corruption and water stealing. Instead of viewing community governance behaviours based on such relations as simple corruption or elite capture, the negative outcomes came in collective forms, which make them more destructive and harder to detect.

Uses of social capital have also fuelled collective exploitation of water resource, especially groundwater resources since related information was limited and difficult to monitor or control by external authorities. The Wang village in the middle reaches (See Figure 3) is a good case in point. It had 12 communities, farming and irrigating $10080 \mathrm{mu}$ of land $(1 \mathrm{mu}=0.067 \mathrm{ha}$ ) while paying only for official water quotas allocated to around $2900 \mathrm{mu}$ which is the officially registered irrigation area. From the perspectives of community members, using these multi-level relations and linkages is unwritten rule and a necessity for them to simply get by and make a living out of irrigated agriculture today, in a world of "Wielding and yielding of power over water". It is such networks of power rather than physical scarcity itself that determine how water is governed, collective action is organized and for what purposes. This shows that social actions or interactions depend on local socio-political environment, for example what kind of network exists, and the nature of these relationships (Mehta, 2003). 
Governance institutions and other external agencies should find a way to better understand the roles of social capital and collective action and work with locals rather than against them (Berkes, 2009).The State has a very significant role in governance of the CPRs (Mansbridge, 2014). For example, it can provide information, negotiation platform and appropriate incentives for diverse stakeholders, all of which local communities cannot achieve themselves. However it is equally critical to distinguish the state's capability in formulating water policies and in implementing them in practice as proposed. As shown water reforms or any other water policies in general should be neither top-down nor bottom-up, but a polycentric process across multiple levels that works the best in particular contexts (Elinor Ostrom, 2010).

\section{Conclusion}

The aim of this paper is to better understand CBWG under government-enforced IWRM reforms and identify implications for future water policy development, implementation and governance. The result is consistent with the general agreement that successful water governance should be integrated, cooperative and polycentric recognizing multiple needs, objectives and processes across various levels (Biswas, 2008). Managing multi-level relation in fact is an indispensable part of CBWG in a country such as China where use of relations to pursue one's interest is so prevalent that it is almost legal. This paper highlights how one-level community-based mechanism is insufficient and probably no more effective than state-centred or market-led approach. Limited consideration of the significant roles of existing irrigation institutions and multi-level linkages in water governance can created a range of unexpected and negative outcomes, such as collective destructive water behaviour and increasing rent-seeking of officials which have become new and reinforced "norms" for communities.

Water reforms such as IWRM which seeks to facilitate integrated and sustainable water management needs to be built on clearer understanding of the complex characteristics of diverse stakeholders and extant institutions at local levels as well as the multi-level interactions and their impacts on different groups. A key consideration for successful CBWG is to involve communities as participants and partners in a polycentric process rather than just as passive recipients or beneficiaries in a top-down hierarchy, which the author believe is one of the major reasons for the water governance failures.

\section{Acknowledgement}

The research was made possible by a project funded by the Chinese Scholarship Council-University of Oxford Scholarship. The field work leading to this paper was also supported by Research Grant from the Great Britain China Centre in 2012. The author would also like to thank all the participants for sharing their experiences and the three anonymous referees for their valuable comments.

\section{References}

Adger, W. N. (2010). Social capital, collective action, and adaptation to climate change Der Klimawandel (pp. 327-345): Springer.

Agarwal, B. (2001). Participatory exclusions, community forestry, and gender: An analysis for 
South Asia and a conceptual framework. World Development, 29(10), 1623-1648. http://dx.doi.org/10.1016/S0305-750X(01)00066-3

Agrawal, A. (2014). Studying the commons, governing common-pool resource outcomes: Some concluding thoughts. Environmental Science \& Policy, 36, 86-91. http://dx.doi.org/10.1016/j.envsci.2013.08.012

Akono, E. B. (2013). Irreversibility, Option Demand and Environmental Preservation. Environmental Management and Sustainable Development, 2(2), 1-6

Arnstein, S. R. (1969). A ladder of citizen participation. Journal of the American Institute of planners, 35(4), 216-224. http://dx.doi.org/10.1080/01944366908977225

Baland, J.-M., \& Platteau, J.-P. (2007). Collective action on the commons: the role of inequality. Inequality, cooperation, and environmental sustainability, 10-35

Berkes, F. (2002). Cross-scale institutional linkages: perspectives from the bottom up. In E. Ostrom, T. Dietz, N. Dolsak, P. C. Stern \& E. U. Weber (Eds.), The drama of the commons (pp. 293-321). Washington, DC

National Academy Press.

Berkes, F. (2009). Evolution of co-management: role of knowledge generation, bridging organizations and social learning. Journal of Environmental Management, 90(5), 1692-1702. http://dx.doi.org/10.1016/j.jenvman.2008.12.001

Berkes, F., Colding, J., \& Folke, C. (2000). Rediscovery of traditional ecological knowledge as adaptive management. Ecological Applications, 10(5), 1251-1262. http://dx.doi.org/10.1890/1051-0761(2000)010[1251:ROTEKA]2.0.CO;2

Biswas, A. (2008). Integrated Water Resources Management: Is It Working? International Journal of Water Resources Development, 24(1), 5-22. 10.1080/07900620701871718

Blaikie, P. (2006). Is small really beautiful? Community-based natural resource management in Malawi and Botswana. World Development, 34(11), 1942-1957. http://dx.doi.org/10.1016/j.worlddev.2005.11.023

Brandt, U. S., \& Svendsen, G. T. (2013). Is local participation always optimal for sustainable action? The costs of consensus-building in Local Agenda 21. Journal of Environmental Management, 129(0), 266-273. http://dx.doi.org/10.1016/j.jenvman.2013.07.020

Cleaver, F. (1998). Incentives and informal institutions: Gender and the management of water. Agriculture and Human Values, 15(4), 347-360. http://dx.doi.org/10.1023/A:1007585002325

Cleaver, F. (2000). Moral ecological rationality, institutions and the management of common property resources. Development and Change, 31(2), 361-383. http://dx.doi.org/10.1111/1467-7660.00158

Crase, L., \& Gandhi, V. P. (2009). Reforming Institutions in Water Resource Management: Policy and Performance for Sustainable Development: Earthscan. 
Gastineau, P. (2006). A Water Users Association in Madagascar: Why Does it Fail Building the European Commons: From Open Fields to Open Source, European Regional Meeting of the International Association for the Study of Common Property (IASCP). Brescia, Italy.

Giest, S., \& Howlett, M. (2014). Understanding the pre-conditions of commons governance: The role of network management. Environmental Science \& Policy, 36(0), 37-47. http://dx.doi.org/10.1016/j.envsci.2013.07.010

GWP. (2000). Integrated water resources management. Stockholm.

Huang, Q., Wang, J., Easter, K. W., \& Rozelle, S. (2010). Empirical assessment of water management institutions in northern China. Agricultural Water Management, 98(2), 361-369. http://dx.doi.org/10.1016/j.agwat.2010.09.004

Hussain, I. (2005). Pro-poor intervention strategies in irrigated agriculture in Asia. International Water Management Institute, Colombo, Sri Lanka

Jiang, Y. (2009). China's water scarcity. Journal of Environmental Management, 90(11), 3185-3196. 10.1016/j.jenvman.2009.04.016

Johnson III, S. H. (1997). Irrigation management transfer: Decentralizing public irrigation in Mexico. Water International, 22(3), 159-167. http://dx.doi.org/10.1080/02508069708686695

Jonch-Clausen, T. (2004). Integrated water resources management (IWRM) and water efficiency plans by 2005: Why, what and how (Report No. 1403-5324). Retrieved from TEC Background Papers No.10.

Jordi, G.-A. (2013). Trends in integrated water resources management research: a literature review

Kamoto, J., Clarkson, G., Dorward, P., \& Shepherd, D. (2013). Doing more harm than good? Community based natural resource management and the neglect of local institutions in policy development. Land Use Policy, 293-301. http://dx.doi.org/10.1016/j.landusepol.2013.06.002

Kearney, A. R., \& Bradley, G. A. (2011). The effects of viewer attributes on preference for forest scenes: Contributions of attitudes, knowledge, demographic factors, and stakeholder group membership. Environment and Behavior, 43(2), 147-181. http://dx.doi.org/10.1177/0013916509353523

Lam, W. F., Shivakoti, G., Vermillion, D., Pradhan, U., Yoder, R., \& Ostrom, E. (2005). Asian irrigation in transition: responding to challenges: Sage Publications Pvt. Limited.

Lane, M. B., \& McDonald, G. (2005). Community-based environmental planning: operational dilemmas, planning principles and possible remedies. Journal of Environmental Planning and Management, 48(5), 709-731. http://dx.doi.org/10.1080/09640560500182985

Lee, H., \& Zhang, D. (2004). Perceiving desertification from the lay perspective in northern China. Land Degradation \& Development, 15(6), 529-542. http://dx.doi.org/10.1002/ldr.638 


\section{Ml Macrothink}

Environmental Management and Sustainable Development

ISSN 2164-7682

2014, Vol. 3, No. 2

Lejano, R. P., \& Fernandez de Castro, F. (2014). Norm, network, and commons: The invisible hand of community. Environmental Science \& Policy, 36(0), 73-85. http://dx.doi.org/10.1016/j.envsci.2013.07.012

Liu, B., \& Speed, R. (2009). Water Resources Managemetn in the People's Republic of China. Water Resources Development, 25(2), 16. http://dx.doi.org/10.1080/07900620902868596

Lynam, T., de Jong, W., Sheil, D., Kusumanto, T., \& Evans, K. (2007). A review of tools for incorporating community knowledge, preferences, and values into decision making in natural resources management. Ecology \& Society, 12(1)

Ma, J., Wang, X., \& Edmunds, W. (2005). The characteristics of ground-water resources and their changes under the impacts of human activity in the arid Northwest China--a case study of the Shiyang River Basin. Journal of Arid Environments, 61(2), 277-295. http://dx.doi.org/10.1016/j.jaridenv.2004.07.014

Mansbridge, J. (2014). The role of the state in governing the commons. Environmental Science \& Policy, 36(0), 8-10. http://dx.doi.org/10.1016/j.envsci.2013.07.006

Mbilinyi, B., Tumbo, S. D., \& Mahoo, H. (2005). Indigenous knowledge as decision support tool in rainwater harvesting Physics and Chemistry of the Earth (Vol. 30, pp. 792-798): Elsevier Ltd.

Mehta, L. (2003). Contexts and constructions of water scarcity. Economic And Political Weekly, 5066-5072

Meinzen-Dick, R., \& Knox, A. (1999). Collective action, property rights, and devolution of natural resource management: A conceptual framework. from International Food Policy Research Institute (IFPRI) . http://www.capri.cgiar.org/workshop_devolution.asp

Mollinga, P. P., S, S. V., \& Wester, P. (2008). Water , Politics and Development : Framing a Political Sociology of Water Resources Management. Water Resources Management, 1, 7-23

Mosse, D. (2006). Collective action, common property, and social capital in South India: An anthropological commentary. Economic development and cultural change, 54(3), 695-724. http://dx.doi.org/10.1086/500034

MWR. (2007). 2007 Statistic Bulletin on China Water Activities. Beijing.

Narayan, D. (1995). The Contribution of People's Participation: Evidence from 121 Rural Water Supply Projects. World Bank Review

Nian, L. (2001). Participatory irrigation management: innovation and development of irrigation system (in Chinese). Beijing: China Water Resources and Hydropower Publishing House.

Nickum, J. (2010). Water Policy Reform in China's Fragmented Hydraulic State: Focus on Self-Funded / Managed Irrigation and Drainage Districts. Water Policy, 3, 537-551

Nickum, J. E. (1974). A collective approach to water resource development: the Chinese 
commune system, 1962-1972: University of California.

O'Brien, K. J., \& Li, L. (1999). Selective policy implementation in rural China. Comparative Politics, 167-186. http://dx.doi.org/10.2307/422143

Olson, M. (1965). The logic of collective action: public goods and the theory of groups (Vol. 124): Harvard University Press.

Ostrom, E. (1990). Governing the commons: The evolution of institutions for collective action. New York, USA270: Cambridge Univ Press.

Ostrom, E. (1993). Design principles in long-enduring irrigation institutions. Water Resources Research, 29(7), 1907-1912. http://dx.doi.org/10.1029/92WR02991

Ostrom, E. (2010). Beyond markets and states: polycentric governance of complex economic systems. The American economic review, 100(3), 641-672. http://dx.doi.org/10.1257/aer.100.3.641

Ostrom, E., Burger, J., Field, C. B., Norgaard, R. B., \& Policansky, D. (1999). Revisiting the commons: local lessons, global challenges. Science, 284(5412), 278-282. http://dx.doi.org/10.1126/science.284.5412.278

Pahl-Wostl, C. (2002). Towards sustainability in the water sector - The importance of human actors and processes of social learning. Aquatic Sciences, 64, 394-411. http://dx.doi.org/10.1007/PL00012594

Pretty, J. (2003). Social capital and the collective management of resources. Science, 302(5652), 1912-1914

Rogers, P., \& Hall, A. W. (2003). Effective water governance (Vol. 7): Global Water Partnership Stockholm, Sweden.

Sadiddin, A. (2013). An Assessment of Policy Impact on Agricultural Water Use in the Northeast of Syria. Environmental Management \& Sustainable Development, 2(1)

Savenije, H., \& Vanderzaag, P. (2008). Integrated water resources management: Concepts and issues. Physics and Chemistry of the Earth, Parts A/B/C, 33(5), 290-297. 10.1016/j.pce.2008.02.003

Shen, D. (2012). Planned water use system in China. Water Policy, 14(4), 581-593. http://dx.doi.org/10.2166/wp.2012.156

Solanes, M. (1995). Decentralization of Water Management: The Case of Water Users' Associations Agriculture in Liberalizing Economies: Changing Roles for Governments: Proceedings of the Fourteenth Agricultural Sector Symposium (pp. 211): World Bank Publications.

Sonal, B. (2013). How does participatory irrigation management work? A study of selected water users' associations in Anand district of Gujarat, western India. Water Policy, 15, 223-242. http://dx.doi.org/10.2166/wp.2012.065 
Stephen R. Kellert, J. N. M. S. A. E. L. L. L. (2000). Community Natural Resource Management: Promise, Rhetoric, and Reality. Society \& Natural Resources, 13(8), 705-715. 10.1080/089419200750035575

Suich, H. (2013). The effectiveness of economic incentives for sustaining community based natural resource management. Land Use Policy, 31, 441-449. http://dx.doi.org/10.1016/j.landusepol.2012.08.008

Tang, S. Y. (1992). Institutions and collective action: Self-governance in irrigation: ICS press. Tortajada, C. (2010). Water Governance: Some Critical Issues. International Journal of Water Resources Development, 26(2), 297-307. 10.1080/07900621003683298

Wade, R. (1987). The management of common property resources: finding a cooperative solution. The World Bank Research Observer, 2(2), 219-234. http://dx.doi.org/10.1093/wbro/2.2.219

Wang, J., Huang, J., Zhang, L., Huang, Q., \& Rozelle, S. (2010). Water Governance and Water Use Efficiency: The Five Principles of WUA Management and Performance in China. JAWRA Journal of the American Water Resources Association, 46(4), 665-685

Williams, J. (1998). Knowledge, consequences, and experience: The social construction of environmental problems. Sociological Inquiry, 68(4), 476-497. http://dx.doi.org/10.1111/j.1475-682X.1998.tb00481.x

Xie, M. (2007). Global development of farmer water user associations (WUAs): lessons from South-East Asia Proceedings of the Regional Workshop on WUAs Development: Water Users' Associations Development in Southeastern European Countries. Bucharest, Romania.

Yu, H., Edmunds, M., Lora-Wainwright, A., \& Thomas, D. S. G. (2014). Design principles, social capital and collective action in governing the water commons- a comparative assessment of irrigation institutions in contemporary China (in proof, forthcoming). International Journal of Water Resources Development

Yu, H., Lora-Wainwright, A., Edmunds, M., \& Thomas, D. (2013). Villagers' perceptions of Water Crises and teh Influencing Factors of Local Perceptions : A Case Study in the Shiyang River Basin, Northwest China. The Journal of Transdisciplinary Environmental Studies, 12(2), $13-27$

\section{Copyright Disclaimer}

Copyright for this article is retained by the author(s), with first publication rights granted to the journal.

This is an open-access article distributed under the terms and conditions of the Creative Commons Attribution license (http://creativecommons.org/licenses/by/3.0/). 